Eur. J. Clin. Chem. Clin. Biochem.

Vol. 30, 1992, pp. $11-14$

(c) 1992 Walter de Gruyter \& Co.

Berlin · New York

\title{
Recovery of Proteins from the Broncho-Alveolar Lavage Fluid Proposal for a Standardisation
}

\author{
By U. Schumacher $\left.{ }^{1}\right)$, A. Mausolf, J. Barth, U. Welsch and W. Petermann \\ Anatomische Anstalt der Ludwig Maximilians Universität München
}

(Received June 3/October 14, 1991)

Dedicated to O. T. A. Watermann, MD on the occasion of his retirement from active duty of the Rodenwaldt Institute

Summary: In this study various precipitation methods have been used to concentrate the proteins from broncho-alveolar-lavages. The highest percentage of proteins was recoverd from the broncho-alveolar-lavages using the method of Wessel \& Flügge (Anal. Biochem. 138 (1984) 141-143). The recovered proteins were further analysed by SDS-polyacrylamide gel electrophoresis. Except for low molecular mass proteins, the method of Wessel \& Flügge proved to be the most effective for the recovery of individual proteins. In general, the method of Wessel \& Flügge seems to be the superior method for concentrating proteins of bronchoalveolar-lavages for further analysis.

\section{Introduction}

During the last few years much attention has been paid to the study of the proteins which can be recovered from broncho-alveolar-lavages. Although quantification of the epithelial lining fluid is difficult (1), many studies have quantitated different proteins in broncho-alveolar-lavages such as $\alpha_{1}$-proteinase inhibitor (2), complement (3), immunoglobulins (4) and glycoproteins (5). However, studies dealing with a range of proteins in the broncho-alveolar-lavages are less frequent (6).

A comparison of the results from the above mentioned authors is difficult to interpret, since different concentration methods including ultrafiltration, ultracentrifugation (7) and precipitation reactions (8) were used.

In this report an attempt has been made to establish a standard protocol for determining protein concentrations in broncho-alveolar-lavages. One prerequisite

') This study was supported by a grant from the FriedrichBaur-Stiftung. for a suitable method was practicality, e. g. requiring no specialised equipment such as ultracentrifuges or nitrogen concentration chambers. Various precipitation methods were used to concentrate the proteins and their efficiency was determined by protein measurement and by sodium dodecylsulphate polyacrylamide gel electrophoresis (SDS-PAGE). This approach furthermore opens the possibility of analysing proteins in the lavage from several species, since, in contrast to e.g. radioimmunoassay, immunological techniques involving antibodies are not used for estimating protein concentrations.

\section{Material and Methods}

The lavages were taken from segments of lung free of carcinoma in patients with lung cancer. The middle lobe or the lingula was taken for lavage (9). Broncho-alveolar-lavage was performed by using $5 \times 20 \mathrm{ml}$ physiological saline in all cases. The recovery rate was always above $60 \%$.

For electrophoresis, $50 \mathrm{ml}$ aliquots from each of eight bronchoalveolar-lavages were pooled for each experiment, after careful removal of cellular components by centrifugation at $200 \mathrm{~g}$ for $15 \mathrm{~min}$. Samples $(20 \mathrm{ml})$ of the pooled broncho-alveolar-lavages were treated in the following ways: 
1. Addition of trichloroacetic acid (Merck, Darmstadt, Germany) to the samples at 50, 75, 100 and $200 \mathrm{~g} / \mathrm{l}$ final concentration. The lavages were incubated with the trichloroacetic acid for $30 \mathrm{~min}$ in an ice bath. The proteins were collected by centrifugation for $10 \mathrm{~min}$ at $13000 \mathrm{~g}$ (Sorvall SS-34 rotor). The pellet was washed in ethanol and centrifuged again. The remaining pellet was resuspended in $1 \mathrm{ml}$ bidistilled water containing $10 \mu \mathrm{l}$ of a $200 \mathrm{~g} / \mathrm{l}$ sodium dodecyl sulphate (SDS) solution and $50 \mu \mathrm{l} \mathrm{NaOH}(1 \mathrm{~mol} / \mathrm{l})$.

2. $20 \mathrm{ml}$ of a cold saturated ammonium sulphate solution (Merck, Darmstadt, Germany) were added. After 12 hours at $4{ }^{\circ} \mathrm{C}$ the proteins were sedimented by centrifugation $(13000 \mathrm{~g}, 10 \mathrm{~min})$.

3. Two other aliquots $(20 \mathrm{ml}$ each $)$ were treated with either 80 $\mathrm{ml}$ acetone or ethanol (both obtained as pro analysi quality from Merck, Darmstadt, Germany) for $30 \mathrm{~min}$. The proteins were collected by centrifugation (as above).

4. 0.3 grams of polyethyleneglycol $\left(M_{\mathrm{r}} 6000-8000\right.$, Sigma, Deisenhofen, Germany) were added and stirred for $12 \mathrm{~h}$ at room temperature and the proteins were pelleted by centrifugation (as above).

5. Finally, a sample was treated by the method of Wessel \& Flügge (10). In brief, to a $20 \mathrm{ml}$ sample $80 \mathrm{ml}$ methanol (Merck, Darmstadt, Germany) were added, vortexed and centrifuged $(10 \mathrm{~s}$ at $9000 \mathrm{~g}$ ). Chloroform $(20 \mathrm{ml})$ (Merck, Darmstadt, Germany) was added and after vortexing the centrifugation was repeated. After the addition of $60 \mathrm{ml}$ water, the samples were vigorously vortexed and centrifuged again $(1 \mathrm{~min}$ at $900 \mathrm{~g}$ ). The upper phase was discarded and additional methanol $(60 \mathrm{ml})$ was added. After mixing, the proteins were pelleted by centrifugation for $2 \mathrm{~min}$ at $9000 \mathrm{~g}$.

All pellets were redissolved in $1 \mathrm{ml}$ bidistilled water, and $10 \mu \mathrm{l}$ of a SDS-solution $(200 \mathrm{~g} / \mathrm{l})$ were added if necessary (in 1 and 3). Protein was determined according to the method of Lowry et al. (11) with bovine serum albumin as a standard. Proteins $(50 \mu \mathrm{g}$ per slot) were applied in a SDS polyacrylamide gel electrophoresis (SDS-PAGE) according to Laemmli (12), using a $12.5 \%$ gel. The gels were run at $40 \mathrm{~mA}$. After the termination of the run, the gels were fixed and stained with Coomassie Brilliant Blue (Sigma, Deisenhofen, Germany). The molecular masses of the protein bands (molecular mass markers were obtained from Sigma, Deisenhofen, Germany) in Coomassie Brilliant Blue stained gels were calculated by a "gel" standard molecular mass program on a VAX computer at the MaxPlanck-Institute of Biochemistry, München.

\section{Results}

The amount of protein assayed by the different methods ranges from $0.69 \mathrm{mg}$ protein per $20 \mathrm{ml}$ lavage fluid recovered after $200 \mathrm{~g} / 1$ trichloroacetic acid precipitation to $1.86 \mathrm{mg}$ protein concentrated by the method of Wessel \& Flügge; for other results see table 1. The separation of the recovered proteins by the SDS-PAGE resulted in various protein bands as shown in the Coomassie Brilliant Blue stain of the gel (fig. 1). The different efficiencies of protein recovery are obvious. The apparent molecular masses, which were calculated from the standard molecular mass markers, are listed in table 2.

Electrophoresis shows that the most efficient solubilisation of proteins after pelleting was achieved with the Wessel \& Flügge method.
Tab. 1. Efficiency of protein recovery by various precipitation reactions and methods. The percentage of recovery from the undiluted fluid is indicated in brackets in \% $(1.90 \mathrm{mg}=100 \%$ as measured in the original fluid; \pm SD from five experiments in \%). Protein recovery was measured by the Lowry method with bovine serum albumin as a standard.

\begin{tabular}{lll}
\hline \multirow{2}{*}{ Precipitating method } & \multicolumn{2}{l}{ Recovery from $20 \mathrm{ml}$ lavage } \\
& mg & $\%$ \\
\hline $50 \mathrm{~g} / \mathrm{l}$ trichloroacetic acid & 1.14 & $60.0 \pm 12.0$ \\
$75 \mathrm{~g} / \mathrm{l}$ trichloroacetic acid & 1.10 & $57.9 \pm 9.0$ \\
$100 \mathrm{~g} / \mathrm{l}$ trichloroacetic acid & 1.00 & $52.6 \pm 13.0$ \\
$200 \mathrm{~g} / \mathrm{l}$ trichloroacetic acid & 0.69 & $36.3 \pm 16.0$ \\
$500 \mathrm{~g} / \mathrm{l}$ ammonium sulphate & 1.01 & $53.2 \pm 6.0$ \\
$800 \mathrm{ml} / \mathrm{l}$ ethanol & 1.02 & $53.7 \pm 8.0$ \\
$800 \mathrm{ml} / \mathrm{l}$ acetone & 1.29 & $67.9 \pm 11.0$ \\
$150 \mathrm{~g} / \mathrm{l}$ polyethylene glycol & 1.09 & $57.4 \pm 8.0$ \\
Wessel \& Flügge & 1.86 & $97.9 \pm 7.0$ \\
\hline
\end{tabular}

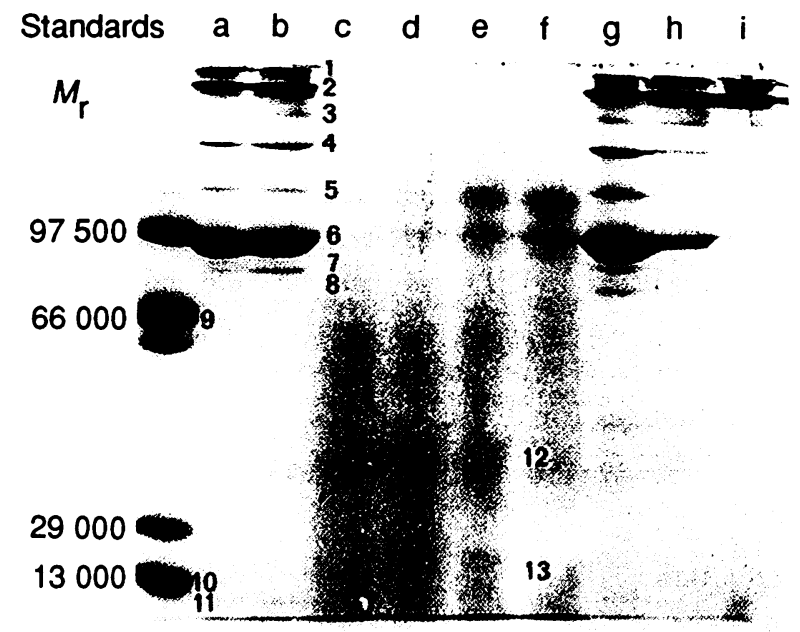

Fig. 1. Gel electrophoresis of human broncho-alveolar-lavages concentrated by various methods: left lane: molecular mass standards; lane a, broncho-alveolar-lavages concentrated with acetone;

lane $b$, concentrated with ethanol;

lane $\mathrm{c}-\mathrm{f}$, broncho-alveolar-lavages concentrated with $200,100,75,50 \mathrm{~g} / 1$ trichloroacetic acid respectively; lane g, concentrated according to Wessel \& Flügge; lane $\mathrm{h}$, ammonium sulphate concentrate; lane $i$, polyethyleneglycol concentrate (PEG).

The number of the protein bands stained refer to table 2 .

\section{Discussion}

This study compares the efficiency of several protein precipitation methods for the recovery of proteins from broncho-alveolar-lavages. With respect to the absolute amount of protein, the method of Wessel \& Flügge is the superior method for determination of the protein concentration of broncho-alveolar-lavages. In the analysis of the protein species in the lavage fluid, however, a few low molecular mass bands 
Tab. 2. Molecular masses as determined by SDS-PAGE of proteins recovered from the broncho-alveolar-lavages. The protein band numbers refer to those in figure 1 .

\begin{tabular}{lll}
\hline $\begin{array}{l}\text { Protein } \\
\text { band } \\
\text { No. }\end{array}$ & $\begin{array}{l}\text { Running } \\
\text { distance } \\
(\mathrm{cm})\end{array}$ & $\begin{array}{l}\text { Calculated relation } \\
\text { molecular mass } \\
\text { in } 10^{3}\end{array}$ \\
\hline 1 & 0.10 & $137.4 \pm 0.3$ \\
2 & 0.30 & $130.6 \pm 0.3$ \\
3 & 0.75 & $115.4 \pm 0.2$ \\
4 & 1.25 & $100.9 \pm 0.2$ \\
5 & 2.10 & $80.3 \pm 0.2$ \\
6 & 3.00 & $63.1 \pm 0.1$ \\
7 & 3.35 & $57.4 \pm 0.1$ \\
8 & 3.70 & $52.3 \pm 0.1$ \\
9 & 4.10 & $47.0 \pm 0.0$ \\
10 & 8.60 & $14.0 \pm 0.0$ \\
11 & 8.90 & $13.0 \pm 0.0$ \\
12 & 6.50 & $24.6 \pm 0.1$ \\
13 & 8.00 & $16.5 \pm 0.0$ \\
\hline
\end{tabular}

in the SDS-PAGE were more prominent in the trichloroacetic acid-precipitated material than after the concentration method of Wessel \& Flügge. Staining of the protein bands with Coomassie Brilliant Blue in the SDS-PAGE offers the opportunity to determine the quantities of proteins present, since Coomassie Brilliant Blue binds to proteins in a stoichiometric fashion (13).

Although there is no precise method for evaluating protein concentrations in bronchial alveolar lining fluid, the concentration and subsequent analysis of proteins may be valuable for clinical diagnosis. SDSPAGE allows separation of proteins according to their molecular masses and it may therefore be used to demonstrate leaks in the blood-air-barrier. Promising results in a similar situation have already been obtained by application of SDS-PAGE in the classification of glomerular disease (14). Although presumably not all proteins are pelleted with the same efficiency, the method of Wessel \& Flügge combined with
SDS-PAGE gives a good general indication of protein leakage into the alveolar space. This is especially true when it is taken into account that the recovery rate exceeds $95 \%$, making the loss of some proteins therefore almost negligible. This recovery rate seems to be a very satisfactory one, indicating that this method may well serve as a standard method for analysing proteins of the broncho-alveolar-lavages. The protein loss using other methods to concentrate proteins in dilute solutions, such as lyophilisation and subsequent dialysis (necessary in the case of broncho-alveolarlavages since the lavage is done with physiological saline), before applying the samples to electrophoresis, may well be of the same order. In such cases, minor protein loss may occur due to adhesion of proteins to dialysis tubes and due to leakage of low molecular mass proteins into the dialysis fluid, resulting in a loss of low molecular mass components similar to that observed in the Wessel \& Flügge method in this study. Furthermore, this method has the advantage over other methods, e.g. lyophilisation, that it does not need sophisticated laboratory equipment and is therefore very economical to perform. Additionally, this method can be used for the study of broncho-alveolarlavages from experimental animals since it does not require antibodies. In contrast radioimmunoassays or enzyme-linked immunosorbent assays employ antibodies, and they are sometimes species specific and therefore not applicable for cross species use. The diagnostic value of this method is still unclear. To draw an analogy, the relative amounts of serum proteins, which are determined by serum electrophoresis, are valuable parameters in diagnostic clinical chemistry, and a similar situation may arise in the analysis of the proteins of the broncho-alveolar-lavages. The identification of individual protein bands recovered can be achieved by Western blotting with the appropriate antibodies. Standardisation, however, is the first prerequisite for any meaningful further analysis.

\section{References}

1. Marcy, T. W., Merril, W. W., Rankin, J. A. \& Reynolds, H. Y. (1987) Limitations of using urea to quantify epithelial lining fluid recovered by bronchoalveolar lavage. Am. Rev. Respir. Dis. 135, 1276-1280.

2. Stockley, R. A. \& Afford, S. C. (1984) Qualitative studies of $\alpha-1$ proteinase inhibitor. Hoppe-Seyler's Z. Physiol. Chem. 365, 503-510.

3. Lambre, C. R., Le Maho, S., di Bella, G., de Cremoux, H., Atassi, K. \& Bignon, J. (1986) Bronchoalveolar lavage fluid and serum complement activity in pulmonary sarcoidosis. Am. Rev. Respir. Dis. 134, 238-242.

4. Calvanico, N. J., Ambegaonkar, S. P., Schlueter, D. P. \& Fink, J. N. (1980) Immunoglobulin levels in bronchoalveolar lavage fluid from pigeon breeders. J. Lab. Clin. Med. 96, $129-140$.

5. Satoh, K., Arai, H., Yoshida, T., Ito, M., Nagai, H., Sato, H. \& Motomiya, M. (1983) Glycosaminoglycans and glycoproteins in bronchoalveolar lavage fluid from patients with pulmonary alveolar proteinosis. Inflammation 7 , $347-353$.

6. Müller, B. \& von Wichert, P. (1984) Identical serum proteins and specific bronchoalveolar lavage proteins in the adult human and the rat. Am. Rev. Respir. Dis. 130, 674-677.

7. Chapman, H. A., Stahl, M., Allen, C. L., Yee, R. \& Fair, D. S. (1988) Regulation of the procoagulant activity within the bronchoalveolar compartment of normal human lung. Am. Rev. Respir. Dis. 137, 1417-1425.

8. Chapman, H. A., Reilly, J. J. \& Kobzik, L. (1988) Role of plasminogen activator in degeneration of extracellular matrix protein by live human alveolar macrophages. Am. Rev. Respir. Dis. 137, 412-419. 
9. Hunninghake, G. W., Gadek, J. E., Kawanami, O., Ferrans, V. J. \& Crystal, R. G. (1979) Inflammatory and immune processes in the human lung in health and disease: evaluation by bronchoalveolar lavage. Am. J. Pathol. 97, 149204.

10. Wessel, D. \& Flügge, U. (1984) A method for the quantitative recovery of protein in dilute solution in the presence of detergents and lipids. Anal. Biochem. 138, 141-143.

11. Lowry, O. H., Rosebrough, N. J., Farr, A. L. \& Randall, R. J. (1951) Protein measurement with Folin phenol reagent. J. Biol. Chem. 193, 265-275.
12. Laemmli, U. K. (1970) Cleavage of structural proteins during the assembly of the head of the bacteriophage T 4 Nature 227, 680-685.

13. Bradford, M. M. (1976) A rapid and sensitive method for the quantitation of microgram quantities of protein utilising the principle of protein dye binding. Anal. Biochem. 72, $248-254$.

14. Reichel, W., Wolfrum, D. I., Klein, R. \& Scheler, F. (1976) Differenzierung der Proteinurie durch die Mikrogelelektrophorese in kontinuierlichen Polyacrylamid-Gradientengelen. Klin. Wochenschr. 54, 19-24.

Prof. Dr. U. Schumacher

Human Morphology

University of Southampton

Bassett Cressent East

Southampton

SO9 3TU

England 